\title{
Terapi Menulis Pengalaman Emosional Dalam Penurunan Gangguan Stres Pasca Trauma Pada Penyintas Bencana
}

\author{
Hario Abrianto \\ Fina Hidayati \\ Yusuf Ratu Agung \\ Fakultas Psikologi Universitas Islam Negeri Maulana Malik Ibrahim Malang \\ harioabrianto@gmail.com
}

\begin{abstract}
Abstrak
Bencana banjir melanda Pacitan bulan November Tahun 2017 silam meninggalkan dampak fisik yang buruk, di sisi lain bencana juga dapat menimbulkan dampak ketidakseimbangan psikologis atau gangguan psikologis pada korbannya terutama setelah kejadian bencana tersebut. Salah satu gangguan psikologis yang dialami oleh penyintas bencana adalah gangguan stres pasca trauma. Salah satu terapi atau intervensi psikologi yang biasa digunakan dalam menangani gangguan-gangguan psikologis adalah terapi menulis pengalaman emosional atau menulis ekspresif. Tujuan dari penelitian ini untuk mengetahui pengaruh terapi menulis pengalaman emosional terhadap upaya penurunan gangguan stres pasca trauma. Metode penelitian yang digunakan adalah metode penelitian kuantitatif eksperimen dengan model rancang two groups pretest-posttest dan jumlah subjek sebanyak 10 orang pada kelompok eksperimen dan 10 orang pada kelompok kontrol. Subjek merupakan penyintas bencana banjir pacitan yang berada di MA Pembangunan PP Al-Fattah Kikil Arjosari Pacitan. Data diperoleh melalui observasi dan skala modifikasi IES-R untuk mengukur tingkat gangguan stres pasca trauma. Hasil analisis data menggunakan Paired sample $t$ Test untuk kelompok eksperimen menunjukkan penurunan skor yang signifikan dengan $t=5,304$ dan signifikansi $p=0,000<0,05$ sedangkan kelompok kontrol menunjukkan ada penurunan yang tidak signifikan dengan $t=2,129$ dan signifikansi 0,062 >0,05. Sehingga dapat disimpulkan bahwa terapi menulis pengalaman emosional memberikan pengaruh terhadap penurunan tingkat gangguan stres pasca trauma pada penyintas bencana banjir Pacitan di MA pembangunan PP Al-Fattah Kikil Arjosari Pacitan.
\end{abstract}

Kata kunci: terapi menulis pengalaman emosional, gangguan stres pasca trauma, penyintas bencana

\begin{abstract}
The flood disaster that hit Pacitan in November 2017 left a bad physical impact, on the other hand the disaster can also have an impact of psychological imbalance or psychological disturbance on the victims especially after the disaster event. One of the psychological disorders experienced by disaster survivors is post-traumatic stress disorder. One of the therapies or psychological interventions commonly used in dealing with psychological disorders is the therapy of writing emotional experiences or expressive writing. The purpose of this study was to determine the effect of emotional experience writing therapy on efforts to reduce post-traumatic stress disorder. The research method used was a quantitative experimental research method with a two groups pretest-posttest design model and the number of subjects was 10 people in the experimental group and 10 people in the control group. The subject was a pacitan flood survivor who was in the MA in the Development of PP Al-Fattah Kikil Arjosari Pacitan. Data obtained through observation and scale modification of IES- $R$ to measure the level of posttraumatic stress disorder. The results of data analysis using Paired sample $t$ Test for the experimental group showed a significant decrease in scores with $t=5,304$ and significance $p=0,000<0.05$ while the control group showed an insignificant decrease with $t=2.129$ and significance of $0.062>0.05$. So it can be concluded that the emotional experience writing therapy has an effect on reducing the level of post-traumatic stress disorder in survivors of the Pacitan flood disaster in the MA in the development of PP Al-Fattah Kikil Arjosari Pacitan.
\end{abstract}

Keywords: Therapeutic writing, emotional experiences, post traumatic stress disorder, survivors of disaster

(C) 2018 Universitas Muria Kudus 


\section{PENDAHULUAN}

Dampak dari bencana banjir di kabupaten Pacitan mengakibatkan lebih dari 4000 jiwa warga perlu dievakuasi dan diungsikan. Banjir juga mengakibatkan kerusakan pada fasilitas publik dan rumah-rumah warga. Jalur-jalur arah menuju dan dari Kabupaten Pacitan dipastikan lumpuh total, hal tersebut mengakibatkan akses warga menjadi sulit dan menjadikan wilayah kabupaten Pacitan terisolir dari daerah yang lain. Bantuan bantuan dari berbagai pihak sulit untuk disalurkan karena hal tersebut.

Seperti yang telah disebutkan di atas. Selain itu, menimbulkan dampak fisik yang buruk, bencana juga dapat menimbulkan dampak ketidakseimbangan psikologis pada korban terutama setelah kejadian bencana tersebut. Kehilangan harta benda, lapangan pekerjaan, bahkan beberapa kehilangan anak istri atau suami menimbulkan goncangan jiwa yang buruk. Salah satu gangguan psikologis yang bisa ditimbulkan adalah gangguan stres pasca trauma.

Salah satu terapi atau intervensi psikologi yang biasa digunakan dalam menangani gangguan-gangguan psikologis adalah terapi menulis pengalaman emosional atau menulis ekspresif.

Terapi menulis pengalaman emosional adalah suatu cara atau upaya untuk mengungkapkan pikiran dan perasaan yang mendalam mengenai suatu peristiwa tertentu yang menimbulkan emosi pada seseorang kedalam bentuk kata-kata melalui tulisan tangan. Gangguan stres pasca trauma adalah keadaan cemas pada seseorang yang cenderung berkepanjangan sebagai hasil dari pengalaman akan suatu kejadian traumatis seperti mengalami musibah bencana, kekerasan, kehilangan orang yang dicintai, dan sebagainya. Hipotesis pada penelitian ini adalah adanya pengaruh terapi menulis pengalaman emosional terhadap gangguan stres pasca trauma pada penyintas bencana.

\section{METODE PENELITIAN}

Penelitian ini menggunakan metode penelitian kuantitatif Eksperimen dengan model rancang two groups pretest-posttest. Pada penelitian ini variabel bebasnya adalah terapi menulis pengalaman emosonal, sedangkan variabel terikat pada penelitian ini yakni gangguan stres pasca trauma. Populasi dalam penelitian ini adalah siswa MA Pembangunan P Al-Fattah Kikil Arjosari Pacitan, dengan pengambilan sampel menggunakan teknik purposive sampling sebanyak 20 siswa.

Instrumen penelitian pada penelitian ini menggunakan skala adaptasi dari Impact of Event Scale-Revised (IES-R) sebagai pretest dan posttest untuk mengukur tingkat gangguan stres pasca trauma sebelum dan sesudah perlakuan. Perlakuan yang diberikan kepada subjek berupa terapi menulis pengalaman emosional. Dalam penelitian ini teknik analisis menggunakan Paired Sample T-Test. 
HASIL

Hasil dari uji normalitas data yang dilakukan disajikan dalam bentuk tabel sebagai berikut :

Tabel 1. Uji Normalitas Kelompok Eksperimen

\begin{tabular}{l|l|l|l} 
& \multicolumn{3}{l}{ Shapiro-Wilk } \\
\hline $\begin{array}{l}\text { Kelompok } \\
\text { Eksperimen }\end{array}$ & Statistic & Df & Sig. \\
\hline Pre-test & 0,947 & 10 & 0,630 \\
\hline Post-test & 0,944 & 10 & 0,593
\end{tabular}

Berdasarkan hasil uji normalitas data, ditunjukkan oleh Shapiro-Wilk test yaitu pre-test dan post-test memiliki nilai > 0,05 yang berarti sebaran dikatakan normal. Hasil pre-test memiliki nilai $0,630>0,05$ maka data pre-test terdistribusi normal. Kemudian data post-test memiliki nilai 0,593 > 0,05 maka data post-test terdistribusi normal.

Tabel 2. Uji Normalitas Kelompok Kontrol

\begin{tabular}{l|l|l|l} 
& \multicolumn{3}{l}{ Shapiro-Wilk } \\
\hline $\begin{array}{l}\text { Kelompok } \\
\text { Kontrol }\end{array}$ & Statistic & Df & Sig. \\
\hline Pre-test & 0,890 & 10 & 0,169 \\
\hline Post-test & 0,894 & 10 & 0,186
\end{tabular}

Berdasarkan hasil uji normalitas data, ditunjukkan oleh Shapiro-Wilk test yaitu pre-test dan post-test memiliki nilai $>0,05$ yang berarti sebaran dikatakan normal. Hasil pre-test memiliki nilai $0,169>0,05$ maka data pre-test terdistribusi normal. Kemudian data post-test memiliki nilai 0,186 > 0,05 maka data post-test terdistribusi normal.

Hasil dari Uji statistik deskriptif disajikan dalam bentuk tabel sebagai berikut :

Tabel 3. Hasil statistik deskriptif kelompok eksperimen

\begin{tabular}{l|l|l|l|l}
\hline & N & Minimum & Maximum & Mean \\
\hline Pre-test & 10 & 24 & 40 & 32,80 \\
\hline Post-test & 10 & 5 & 25 & 16,60 \\
\hline Valid & 10 & & & \\
\hline
\end{tabular}

Berdasarkan tabel di atas dapat dilihat bahwa nilai minimum kelompok eksperimen saat pre-test 24 dan saat post-test menjadi 5, nilai maximum saat pre-test 40 dan saat posttest menjadi 25 , nilai mean saat pre-test 32,80 dan saat post-test mengalami penurunan menjadi 16,60 . Untuk itu dapat disimpulkan bahwa nilai mean, minimum, dan maximum pada subjek memiliki penurunan skor. 
Tabel 4. Hasil statistik deskriptif kelompok kontrol

\begin{tabular}{l|l|l|l|l}
\hline & $\mathbf{N}$ & Minimum & Maximum & Mean \\
\hline Pre-test & 10 & 24 & 37 & 29,20 \\
\hline Post-test & 10 & 14 & 35 & 22,90 \\
\hline Valid & 10 & & & \\
\hline
\end{tabular}

Berdasarkan tabel di atas dapat dilihat bahwa nilai minimum kelompok kontrol saat pre-test 24 dan saat post-test menjadi 14, nilai maximum saat pre-test 37 dan saat post-test menjadi 35 , nilai mean saat pre-test 29,20 dan saat post-test mengalami penurunan menjadi 22,90. Oleh karena itu, dapat disimpulkan bahwa nilai mean, minimum dan maximum pada subjek memiliki penurunan skor.

Hasil dari analisis Paired sample T-test data disajikan dalam bentuk tabel adalah sebagai berikut :

Tabel 5. Hasil uji paired sample t-test pretest dan posttest kelompok eksperimen

\begin{tabular}{l|l|l|l}
\hline & $\mathrm{N}$ & $\mathrm{T}$ & Sig. (2-tailed) \\
\hline $\begin{array}{l}\text { Pretest } \\
\text { Posttes }\end{array}$ & 10 & 5,304 & 0,000 \\
& & & \\
\hline
\end{tabular}

Dari tabel diatas diketahui bahwa hasil pengukuran paired sample t-test menunjukan $\mathrm{t}$ $=5,304$ dan signifikansi 0,000 $<0,05$ (kesalahan toleransi $5 \%$ ), yang berarti hipotesis diterima dengan menunjukan adanya perbedaan yang signifikan tingkat gangguan stres pasca trauma antara sebelum dan sesudah diberikan perlakuan terapi menulis pengalaman emosional. Sehingga dapat disimpulkan bahwa terapi menulis pengalaman emosional memberikan pengaruh dalam penurunan gangguan stres pasca trauma pada penyintas bencana banjir Pacitan.

Tabel 6. Hasil uji paired sample t-test pretest dan posttest kelompok kontrol

\begin{tabular}{l|l|l|l}
\hline & $\mathrm{N}$ & $\mathrm{T}$ & Sig. (2-tailed) \\
\hline Pretest & 10 & 2,129 & 0,062 \\
Posttes & & & \\
\hline
\end{tabular}

Dari tabel diatas diketahui bahwa hasil pengukuran paired sample t-test menunjukan $\mathrm{t}$ $=2,129$ dan signifikansi $0,062>0,05$ (kesalahan toleransi $5 \%$ ), yang berarti adanya perbedaan yang tidak signifikan tingkat gangguan stres pasca trauma antara sebelum dan sesudah diberikan perlakuan terapi menulis pengalaman emosional. Sehingga dapat disimpulkan bahwa kelompok kontrol yang tidak diberikan terapi menulis pengalamana emosional tidak memberikan pengaruh dalam penurunan gangguan stres pasca trauma pada penyintas bencana banjir Pacitan. 
Hasil uji komparasi kelompok eksperimen dan kelompok kontrol disajikan dalam bentuk tabel adalah sebagai berikut :

\begin{tabular}{l|l|l}
\hline \multirow{2}{*}{ Kelompok } & Mean & \\
\cline { 2 - 3 } & Pre-test & Post-test \\
\hline Eksperimen & 32,80 & 16,60 \\
\hline Kontrol & 29,20 & 22,90 \\
\hline
\end{tabular}

Berdasarkan tabel di atas, di dapatkan mean pre-test kelompok eksperimen 32,80 dan kelompok kontrol 29,20 , yang berarti bahwa hasil pre-test kedua kelompok tersebut hampir sama karena hanya terpaut 3,60. Sedangkan hasil post-test kelompok eksperimen 16,60 dan kelompok kontrol 22,90. Hal tersebut berati antara kelompok eksperimen yang diberi perlakuan dengan kelompok kontrol yang tidak diberi perlakuan sama-sama mengalami penurunan, namun pada kelompok eksperiman mengalami penurunan yang signifikan sedangkan kelompok kontrol tidak karena mean antara kelompok eksperimen dengan kelompok kontrol terpaut cukup jauh yaitu 6,30.

\section{PEMBAHASAN}

Penelitian ini memiliki tujuan untuk mengetahui efektifitas terapi menulis pengalaman emosional terhadap penurunan gangguan stres pasca trauma pada penyintas bencana banjir Pacitan di MA Pembangunan PP Al-Fattah Kikil Arjosari Pacitan. Pengujian hipotesis dilakukan dengan bantuan program SPSS 10.00 for windows menggunakan metode analisis data Paired Sample T Test dengan melihat perbandingan skor skala modifikasi IES-R sebagai pre-test dan post-test.

Berdasarkan analisis uji T dengan gained score yang telah dilakukan, menunjukan bahwa terdapat perbedaan pada tingkat gangguan stres pasca trauma pada subjek yang mengikuti terapi menulis pengalaman emosional. Uji T dengan gained score pretest-posttest pada kelompok eksperimen menunjukan perbedaan yang signifikan dengan $t=5,304$ dan signifikansi $p=0,000<0,05$ (kesalahan toleransi 5\%). Sedangkan kelompok kontrol menunjukkan perbedaan yang tidak signifikan dengan $t=2,129$ dan signifikansi $0,062>0,05$ (kesalahan toleransi 5\%).

Dari hasil penelitian diatas dapat disimpulkan bahwa terapi menulis pengalaman emosional dapat mempengaruhi penurunan tingkat gangguan stres pasca trauma pada penyintas bencana banjir Pacitan di MA Pembangunan PP Al-Fattah Kikil Arjosari Pacitan. Seluruh subjek yang mengikuti terapi menulis pengalaman emosional mengalami perubahan yang positif berupa penurunan skor pretest-posttest, meskipun ada salah satu subjek yang penurunan skornya 1 saja. Dalam terapi menulis pengalaman emosional, subjek diajarkan melatih diri untuk mengeluarkan emosi-emosi dalam bentuk tulisan yang berguna untuk salah 
satu sarana subjek menceritkan hal-hal yang bisa saja tidak ingin diceritakan kepada orang lain.

Hasil penelitian ini sesuai dengan penelitian yang telah dilakukan oleh Purwandari (2004) yang mengatakan bahwa terapi menulis pengalaman emosional efektif untuk menurunkan depresi pada remaja yang mengalami rehabilitasi NAPZA. Penelitian yang lain dilakukan oleh Mankad dkk (2009) tentang dampak terapi menulis pengalaman emosional pada Psycho-Immunological (merupakan studi tentang interaksi antara proses psikologis dengan sistem kekebalan tubuh pada manusia) selama rehabilitasi luka jangka panjang. Hasil penelitian tersebut menunjukan bahwa terapi menulis pengalaman emosional memiliki potensi manfaat terhadap psycho-immunology pada atlet yang menjalani rehabilitasi luka jangka panjang.

Selain itu, menurut Davison dkk (2006) gangguan stres pasca trauma dapat menyebabkan individu menunjukkan gejala seperti merasa terus menerus mengalami kejadian traumatis, tidak bisa menghilangkan kejadian traumatis meski-pun peristiwanya sudah lampau, berkurangnya respon terhadap dunia luar, merasa asing terhadap orang lain, mimpi buruk tentang kejadian traumatis secara terus menerus serta mengalami gangguan tidur. Yang mana hal-hal tersebut jika terjadi terus-menerus akan menyebabkan subjek mengalami kesulitan dalam beraktifitas sehari-hari. Dengan adanya terapi menulis pengalaman emosional yang menurunkan tingkat gangguan stres pasca trauma diharapkan subjek tidak terhambat dalam melakukan aktivitas sehari-hari.

Proses penelitian ini yaitu pemberian perlakuan berupa terapi menulis pengalaman emosional yang ditujukan untuk menurunkan gangguan stres pasca trauma yang dialami oleh para penyintas bencana banjir Pacitan di MA Pembangunan PP Al-Fattah Kikil Arjosari. Hal tersebut dilakukan dengan cara membandingkan skor pre-test atau skor skala modifikasi IES$\mathrm{R}$ sebelum perlakuan dengan skor setelah pemberian perlakuan atau post-test. Hal tersebut dilakukan untuk mengetahui bagaimana pengaruh terapi menulis pengalaman emosional dalam upaya penurunan tingkat gangguan stres pasca trauma yang dialami oleh para penyintas bencana banjir Pacitan di MA Pembangunan PP Al-Fattah Kikil Arjosari.

Proses yang dijalankan selama pemberian terapi menulis pengalaman emosional menurut Davis (1990) berkaitan dengan pengungkapan-pengungkapan emosi yang tidak bisa diungkapkan lewat verbal serta memiliki tujuan untuk menurunkan ketegangan, meningkatkan kemampuan individu dalam menghadapi masalah dan beradaptasi. Dalam penelitian hal ini berguna untuk menurunkan gangguan stres pasca trauma yang di alami oleh penyintas bencana banjir Pacitan di MA Pembangunan PP Al-Fattah Kikil Arjosari. Hasilnya adalah pemberian terapi menulis pengalaman emosional berpengaruh dalam penurunan tingkat gangguan stres pasca trauma. 
Hal tersebut sejalan dengan pendapat yang diungkapkan oleh Pennebeker dan Chung (2007, dalam Rahmawati, 2014) bahwa tujuan dari terapi menulis pengalaman emosional adalah untuk membantu subjek menyalurkan ide, perasaan, dan harapan ke dalam media tertentu yang dapat bertahan lama. Sehingga dapat membantu mengurangi tekanan yang dirasakan oleh subjek dan dapat membantu mereduksi stres. Dalam penelitian ini tekanan dan stres yang dimaksud tersebut adalah gangguan stres pasca trauma yang dialami oleh penyintas bencana banjir Pacitan.

Keberhasilan dalam penelitian ini yang telah dilakukan untuk menurunkan tingkat gangguan stres pasca trauma yang di alami oleh penyintas bencana banjir Pacitan di MA Pembangunan PP Al-Fattah Kikil Arjosari Pacitan dipengaruhi oleh beberapa faktor yaitu modul terapi, fasilitator, dan karakteristik dari subjek. Keberhasilan juga dipengaruhi oleh pemberian kegiatan menulis yang dapat mengungkapkan emosi para subjek dalam sebuah tulisan.

Perlakuan yang diberikan dalam penelitian ini adalah terapi menulis pengalaman emosional yang didampingi oleh seorang fasilitator. Fasilitator disini berperan untuk menjelaskan teknik menulis, memberikan instruksi sesuai prosedur dalam modul dan observasi. Fasilitator juga mendampngi subjek dalam jalannya terapi menulis pengalaman emosional.Keberhasilan juga dipengaruhi oleh pemilihan subjek yang tepat dan sesuai dengan kriteria-kriteria yang sudah dibuat sebelumnya. Kerjasama subjek dalam menjalankan terapi menulis pengalaman emosional juga memiliki andil dalam keberhasilan penelitian ini.

Dalam analisis yang dilakukan peneliti terhadap masing-masing kelompok, yaitu kelompok eksperimen dan kelompok subjek dapat diketahui bahwa subjek yang berada di dalam kelompok eksperimen mengalami penurunan skor tingkat gangguan stres pasca trauma yang berbeda-beda di setiap individunya, meskipun ada yang dalam kategori yang sama, sedangkan subjek dalam kelompok kontol juga mengalami penurunan skor tingkat gangguan stres pasca trauma. Namun, penurunannya sangat sedikit dan tidak signifikan seperti yang terjadi di dalam kelompok eksperimen yang diberikan perlakuan berupa terapi menulis pengalaman emosional.

\section{SIMPULAN}

Hasil penelitian menunjukan terapi menulis pengalaman emosional berpengaruh signifikan untuk menurunkan tingkat gangguan stres pasca trauma pada penyitas bencana banjir Pacitan di MA Pembangunan PP Al-Fattah Kikil Arjosari Pacitan. Hal tersebut diperkuat ketika dilakukan uji deskriptif, uji paired sample t-test dan dapat dilihat dari hasil gain score subjek penelitian. Hasil penelitian ini sesuai dengan hipotesis yang diajukan oleh peneliti. Penelitian ini menunjukan bahwa terapi menulis pengalaman emosional dapat dijadikan 
sebagai pilihan untuk menurunkan tingkat gangguan stres pasca trauma pada penyitas bencana.

\section{SARAN}

Berdasarkan penelitian diatas, diharapkan para subjek dapat menurunkan atau bahkan menghilangkan gangguan stres pasca trauma yang muncul karena kejadian traumatis yaitu bencana banjir. Hal ini agar para subjek dapat menjalankan kehidupan sehari-hari tanpa ada hambatan.

\section{DAFTRA PUSTAKA}

Arikunto, S. (2006). Prosedur Penelitian. Yogyakarta: Rineka Cipta.

Davison, G.C, Neale, J.M, \&Kring, A.M. (2006). Psikologi Abnormal. Jakarta: PT. Raja Grafindo Persada.

Depkes RI Direktorat Jenderal Pelayanan Medis, (1993). PPDGJ III Pedoman Penggolongan dan Diagnosis Gangguan Jiwa Indonesia III, cetakan pertama. Jakarta: Departemen Kesehatan.

Fikri, H. T. (2012). Pengaruh Menulis Pengalaman Emosional dalam Terapi Ekspresif terhadap Emosi Marah pada Remaja. Padang: Humanitas. Vol. 9, No. 2

Latipun. (2002). Psikologi Eksperimen. Malang: UMM Press.

Mankad, A., Gordon, S., \& Wallman, K. (2009). Psycho-Immunological Effects of Written Emotional Disclosure During Long-Term Injury Rehabilitation. Australia: Journal of Clinical Sports Psychology. Vol. 3

Nevid, J.S., Rathus, S.A., \& Greene, B. (2005). Psikologi Abnormal, edisi kelima, Jilid 1. Jakarta: Penerbit Erlangga.

Purwandari, E. (2005). Pengaruh Menulis Pengalaman Emosional Terhadap Memori Otobiografi dan Depresi pada Remaja yang Menjalani Rehabilitasi Napza. Yogyakarta: SOSIOSAINS, 18(2)

Raharja, Randi., dkk. Peran Kearifan Lokal Dalam Mitigasi Bencana: Studi Masyarakat Dalam Menghadapi Bencana Longsor di Desa Bojongkoneng, Kabupaten Bogor. Jurnal Dialog Penanggulangan Bencana. Vol. 7, No. 2, Hal. 111-119

Rahmawati, Marieta. (2014). Menulis Ekspresif Sebagai Strategi Mereduksi Stres Untuk AnakAnak Korban Kekerasan Dalam Rumah Tangga (KDRT). Malang: Jurnal IImiah Psikologi Terapan . Vol. 02, No. 02

Rohmadani, V. Z. (2017). Relaksasi dan Terapi Menulis Ekspresif sebagai Penanganan Kecemasan pada Difabel Daksa. Journal of Health Studies. Vol. 1. No. 1

Rothschild B. The Body Remembers: The Psychophysiology of Trauma and Trauma Treatment. Norton; New York: 2000. 
Salmiyati. 2017. Terapi Menulis Ekspresif Untuk Menurunkan Kecemasan pada Anak Korban Bullying. Tesis. Prodi Magister Psikologi Profesi Fakultas Psikologi USU

Sloan D. M., dkk. (2014). A test of written emotional disclosure as an intervention for posttraumatic stress disorder. NIH-PA Author Manuscript. Vol. 49, No. 4, Hal. 299-304

Susilowati, G. S. (2011). Pengaruh terapi menulis pengalaman emosional terhadap penurunan depresi pada mahasiswa tahun pertama. Yogyakarta: Jurnal Psikologi Volume 38 , No. 1

Tentama, Fatwa. (2014). Dukungan sosial dan post-traumatic stress disorder pada Remana Penyintas Gunung Merapi. Yogyakarta: Jurnal Psikologi Undip. Vol. 13, No. 2

Ulfah, Elyusra. (2013). Intervensi Spiritual Emotional Freedom Technique Untuk Menurunkan Gangguan Stres Pasca Trauma Erupsi Gunung Merapi. Yogyakarta: Journal of Educational, Health and Community Psychology. Vol. 2, No. 1

Warsini, S. (2015). Psychometric evaluation of the Indonesian version of the Impact of Event Scale-Revised. Australia: Journal of Psychiatric and Mental Health Nursing

Zakowski. S. G., dkk. (2004). Written Emotional Disclosure Buffers the Effects of Social Constraints on Distress Among Cancer Patients. America: Health Psychology. Vol. 23, No. 6, 555-563 